\title{
EFEKTIFITAS LOGOTERAPI DALAM MENINGKATKAN KONSEP DIRI DAN KEMAMPUAN MEMAKNAI HIDUP PADA LANSIA
}

\author{
Dwi Heppy Rochmawati ${ }^{1}$, Betie Febriana ${ }^{1}$ \\ ${ }^{1}$ Fakultas Ilmu Keperawatan Universitas Islam Sultan Agung, Semarang \\ dwiheppy@unissula.ac.id
}

\begin{abstract}
Abstrak
Proses hidup lansia telah menghadapi berbagai masalah yang dapat mempengaruhi perkembangan psikologi lansia. Studi terdahulu menemukan bahwa konsep diri dan makna hidup merupakan hal yang paling terpengaruh pada usia lanjut. Jika tidak diatasi, hal ini akan memicu depresi pada lansia. Oleh karena itu, dibutuhkan terapi untuk meningkatkan konsep diri dan kemampuan memaknai hidup lansia. Penelitian ini bertujuan melihat efektifitas logoterapi terhadap peningkatan konsep diri dan kemampuan memaknai hidup lansia di panti. Desain pada penelitian ini adalah kuantitatif dengan Quasi Experimental Pre-Post Test Without Control Group Design. Jumlah sampel sebanyak30 responden dengan teknik simple random sampling. Hasil penelitian ini menunjukkan bahwaperbedaan secara bermakna pada konsep diri (nilai $\mathrm{p}=0,000$ ) dan makna hidup (nilai $\mathrm{p}=0,000$ ) lansia sebelum dan sesudah terapi. Logoterapi merupakan salah satu intervensi yang dapat digunakan pada lansia atau masalah psikososial. Pemberian logo terapi pada lansia berdampak pada peningkatan harga diri lansia dari rendah ketinggi yaitu sebesar 22 responden artinya $73 \%$ terjadi peningkatan harga diri-konsep diri dan ini merupakan angka yang cukup tinggi dan bermakna. Kesimpulan logoterapi efektif untuk meningkatkan konsep diri dan makna hidup lansia di Panti Pelayanan lansia di Panti pelayanan sosial pucang gading Semarang.
\end{abstract}

Kata kunci: Konsep diri, makna hidup, logoterapi, lansia

\begin{abstract}
The effectiveness of logotherapy on improving self-concept and the ability to interpret the life of the elderly.The life process of the elderly has faced various problems that can affect the psychological development of the elderly. Previous studies have found that self-concept and the meaning of life are the most affected in old age. If not overcome, this will trigger depression in the elderly. Therefore, therapy is needed to improve self-concept and the ability to interpret the life of the elderly. This study aims to see the effectiveness of logotherapy on improving self-concept and the ability to interpret the life of the elderly in the institution. The design in this study is quantitative with Quasi Experimental Pre-Post Test Without Control Group Design. The number of samples was 30 respondents with simple random sampling technique. The results of this study indicate that there are significant differences in self-concept ( $p$ value $=0,000)$ and the meaning of life $(p$ value $=0,000)$ the elderly before and after therapy. Logotherapy is one intervention that can be used in the elderly or psychosocial problems. The provision of logotherapy in the elderly has an impact on increasing the self-esteem of the elderly from low to high, which is 22 respondents, meaning that $73 \%$ of the increase in the price of self-concept is self and this is a fairly high and meaningful number. Conclusion Effective logotherapy to improve self-concept and the meaning of elderly life in Panti Elderly services at the social service center of Semarang ivory.
\end{abstract}

Keywords: self-concept, meaning of life, logotherapy, elderly

\section{Pendahuluan}

Lansia adalah bagian dari proses tumbuh kembang. Pada masa ini seseorang mengalami kemunduran fisik, mental dan sosial secara bertahap (Azizah, 2011). Masyarakat menganggap keberadaan lansia menjadi beban keluarga dan masyarakat. Munculnya anggapan tersebut mendorong sebagian masyarakat memandang bahwa panti-panti wredha Unit Rehabilitasi Sosial (URESOS) adalah alternatif yang terbaik untuk dipilih (Hawari, 2004). Kehidupan lansia di URESOS tentu akan berbeda dengan kehidupan lansia yang berada di luar lingkungan URESOS yang para anggotanya dipisahkan dari masyarakat luas.

Proses degeneratif pada lansia berhadapan dengan berbagai masalah yang timbul sehingga dapat mempengaruhi kebermaknaan hidup lansia. Makna hidup 
mempunyai arti yang berbeda pada setiap individu tergantung dari sudut pandang tertentu individu melihat dan mengartikan tentang kehidupannya. Makna hidup adalah hal-hal yang dianggap sangat penting dan berharga serta memberikan nilai khusus bagi seseorang. Kemampuan melakukan kegiatan sehingga layak dijadikan tujuan dalam kehidupan merupakan makna hidup yang banyak berarti bagi lansia. Jika hal itu berhasil dipenuhi maka akan menyebabkan seseorang merasakan kehidupan yang berarti yang pada akhirnya akan menimbulkan perasaan bahagia (Bastaman, 2007).

Konsep harga diri sangat penting karena mempengaruhi sikap individu baik yang berusia lanjut maupun sedang dalam masa menuju tua yang bersifat negatif, sehingga menambah ketakutan terhadap usia lanjut dan menimbulkan konsep diri yang negatif (Hurlock, 2008).

Hasil observasi dan wawancara yang dilakukan terhadap 10 lansia, diperoleh data bahwa 6 lansia mengatakan mereka tidak nyaman dengan keadaan yang sekarang. Mereka ingin memiliki kehidupan yang lebih baik, tetapi mereka tidak memiliki pilihan lain karena kondisi mereka yang tidak mempunyai tempat tinggal. Sedangkan 4 lansia mengatakan senang tinggal di uresos, karena mereka merasa orang lain bisa menghargainya dan menjadi saudara. Adiningsih (2013) menyatakan bahwa terdapat hubungan antara konsep diri dengan makna hidup pada lansia yang tinggal di uresos. Lansia memiliki makna hidup rendah sebanyak 33 lansia (58.9\%) dan 23 lansia $(41.1 \%)$ memiliki makna hidup yang tinggi.

Bastaman (2007) menyatakan bahwa logoterapi adalah teknik untuk menyembuhkan atau mengurangi krisis eksistensial, melalui penemuan makna hidup. Logoterapi dilaksanakan dalam bentuk konseling dan berorientasi pada pencarian makna hidup individu. Tujuan logoterapi adalah meningkatkan makna pengalaman hidup individu yang diarahkan kepada pengambilan keputusan yang bertanggung jawab. Teknik Logoterapi yang dapat digunakan adalah menggunakan intenseparadoksikal, derefleksi, logophilosopy, bimbingan rohani, value awareness technique (VAT).

Tujuan dari penelitian ini adalah Menggambarkan efektifitas logoterapi dalam meningkatkan konsep diri dan kemampuan memaknai hidup pada lansia.

\section{Metode}

Desain yang digunakan dalam penelitian ini adalah Quasi experimental pretest-posttest design without control group dengan intervensilogoterapi. Logoterapi sebagai variabel independen dan konsep diri serta makna hidup sebagai variabel dependen. Logoterapi diberikan dalam 4 sesi yaitu sesi 1 melakukan pengkajian, sesi 2 stimulasi imaginasi kreatif, sesi 3 memproyeksikan nilai-nilai yang dipilih, dan sesi terakhir evaluasi dan terminasi.

Terapi dilakukan sebanyak 4 pertemuan masing-masing pertemuan dilakukan setiap minggu selama 45-60 menit pada masing-masing responden. Sampel sebanyak 30 responden dengan metode total sampling. Responden memiliki kriteria sehat secara kognitif, tidak mengalami dimensia, memiliki pendengaran yang normal, dan memiliki sehat fisik dan mental.

\section{Hasil}

Hasil penelitian menunjukkan bahwa karakteristik lansia mayoritas perempuan sejumlah 19 responden $(72.4 \%)$, dan rentang usia responden paling banyak yaitu usia 55-74 tahun (46.7\%). 
Tabel 1

Karakteristik Responden Lansia $(n=30)$

\begin{tabular}{|c|c|c|c|}
\hline Variabel & Kategori & $\mathrm{f}$ & $\%$ \\
\hline \multirow[t]{3}{*}{ Jenis kelamin } & Laki-laki & 11 & 26,6 \\
\hline & Perempuan & 19 & 72,4 \\
\hline & Total & 30 & 100 \\
\hline \multirow[t]{4}{*}{ Usia } & $55-74$ & 14 & 46,7 \\
\hline & $75-80$ & 9 & 30 \\
\hline & $>80$ & 7 & 23,3 \\
\hline & Total & 30 & 100 \\
\hline
\end{tabular}

\section{Konsep diri sebelum dan sesudah dilakukan logoterapi}

Hasil penelitian menunjukkan bahwa responden yang mempunyai konsep diri rendah sebelum terapi sebanyak 27 responden kemudian menurun menjadi 5 responden dan konsep diri tinggi sebanyak 3 responden kemudian meningkat menjadi 25 responden. Ditunjukkan oleh table bahwa peningkatan konsep diri responden yang memiliki konsep diri rendah menjadi tinggi sebesar 22 responden. Sedangkan dari tinggi menjadi rendah 0 responden. Tabel di atas juga menunjukkan signifikansi 0.000 sehingga dapat disimpulkan bahwa konsepdiri sebelum dan sesudah logoterapi berbeda secara bermakna.

Tabel 2

Konsep diri sebelum dan sesudah dilakukan logoterapi(n=30)

\begin{tabular}{llccc}
\hline & \multicolumn{3}{c}{ Konsep diri sesudah terapi } & p \\
\cline { 2 - 4 } & & Rendah & Tinggi & 0.000 \\
\hline Konsep diri sebelum terapi & Rendah & 5 & 22 & \\
\cline { 2 - 4 } & Tinggi & 0 & 3 & 25 \\
\hline Total & & 5 & 25 \\
\hline
\end{tabular}

\section{Makna hidup sebelum dan sesudah dilakukan logoterapi}

Makna hidup sebelum dan sesudah dilakukan logoterapi pada lansia didapatkan hasil bahwa dari 20 responden mempunyai makna hidup tinggi setelah dilakukan terapi dan 1 responden memiliki makna hidup rendah. Berdasarkan hasil diperoleh kenaikan yang cukup signifikan yaitu sebanyak 20 responden mengalami kenaikan. Nilai $\mathrm{p}$ menunjukkan angka significancy 0.000 sehingga dapat disimpulkan bahwa makna hidup sebelum dan sesudah logo terapi berbeda secara bermakna.

\section{Pembahasan}

Konsep diri pada lansia pada penelitian ini mencakup harga diri pada lansia tentang kemampuan lansia dalam beradaptasi dan memaknai hidup dengan proses degeneratif. Hasil penelitian menunjukkan adanya peningkatan setelah mendapatkan logoterapi mengalami peningkatan bermakna sebelum dan sesudah dilakukan intervensi.

Lansia yang mengalami harga diri rendah disebabkan karena ketidakmampuan dalam beradaptasi dengan perubahan proses degeneratif. Lansia merupakan kelompok umur yang sangat rentan mengalami gangguan kesehatan baik fisik maupun mental. Hampir 20\% dari populasi lansia mengalami gangguan mental spesifik termasuk depresi, alzheimer, penyalahgunaan alkohol dan narkoba, kecemasan, serta kondisi lainnya (Kaplan, Sadock \& Grebb, 2010).

Beberapa perubahan yang terjadi pada lansia antara lain ketidakberdayaan fisik yang menyebabkan ketergantungan 
pada orang lain, ketidakpastian ekonomi sehingga memerlukan perubahan total dalam pola hidupnya, dan mencari teman baru untuk menggantikan mereka yang telah meninggal atau pindah. Masa lansia umumnya mulai merasakan adanya kondisi fisik yang berkurang, misalnya tenaga dan energi berkurang, kulit keriput, tulang rapuh gigi rontok. Oleh karena itu lansia harus menyelaraskan fisik, psikologis dan sosial dengan mengatur pola hidupnya dengan baik misalnya makan bergizi, istirahat cukup dan bekerja secara seimbang.

Perubahan psikososial yang terjadi pada lansiayaitukesadaran atas kematian, perubahan cara hidup, adaptasi dengan orang yang baru dikenal, rasa stress tinggal di Panti, dan masa perawatan terhadap sakitnya. Faktor yang mempengaruhi psikososial pada lansia antara lain masalah finansialmisalnya penghasilan menurun, biaya hidup meningkat,kebutuhan tambahan, biaya pengobatan dan perawatan dalam kondisi penyakit kronis. Faktor lainnya seperti beban psikologis lansia karena penurunankemampuan adaptasi, ketidakmampuan mengendalikan emosi, kehilangan hubungan dengan teman dan keluarga, hilangnya kekuatan dan ketegangan fisik, perubahan konsep diri dan kematian pasangan hidup.

Perubahan kemampuan fisik dan psikososial pada lansia menyebabkan perubahan konsep diri meliputi harga diri rendah pada lansia karena tidak mampu beradaptasi dengan perubahan yang ada baik yang dialami oleh lansia maupun dari lingkungan. Lansia yang mengalami harga diri rendah ditunjukkan dengan terjadi penurunan aktivitas, putus asa, tidak berdaya, sikap terhadap diri yang negatif, kehilangan kepercayaan diri dan bergantung pada orang lain. Harga diri rendah dan gangguan aspek psikologis yang terus menerusakan mengakibatkan depresi diakibatkan oleh ketidakmampuan atau kegagalan dalam memenuhi tugas perkembangan dalam aktualisasi diri.
Logoterapi merupakan salah satu intervensi yang dapat digunakan pada lansia yang mengalami masalah psikososial. Pemberian logoterapi pada lansia berdampak pada peningkatan harga diri lansia dari rendah ke tinggi yaitu sebesar 22 responden (73\%). Hal ini terjadi karena pada logoterapi yang dilakukan dalam empat sesi tentang mengajarkan lansia mengetahui perubahan yang terjadi pada proses menua serta akibat perubahan tersebut pada dirinya sendiri, sehingga diharapkan lansia menyadari perubahan ini dan dapat menerimanya sebagai suatu hal yang normal. Pada sesi keduaya itu menstimulasi imajinasi kreatif lansia, stimulasi ini menstimulasi proses mental lansia dengan menjadikannya kekuatan untuk melakukan hal yang kreatif dan menarik minimal untuk dirinya sendiri. Melalui proses ini diharapkan lansia mampu untuk meningkatkan konsep diri karena telah menemukan dan melakukan hal baru yang akan membantu lansia dalam beraktivitas, menyalurkan energi yang dimiliki sehingga dapat meningkatkan konsep dirinya.

Lewis (2010) mengatakan bahwa melalui intervensi dengan logoterapi, individu dapat melihat jelas tentang dirinya seperti gambaran diri, kepercayaan diri dan kemampuan individu tersebut dalam mekanisme koping. Terapis bertugas mengarahkan lansia untuk melihat kesehatan dari berbagai sisi yang lebih luas dari kondisi keterbatasan, perubahan, masalah dan kemampuan yang dimiliki lansia sehingga lansia mampu untuk tetap bermanfaat untuk dirinya sendiri dan orang lain, misalnya dengan melakukan kegiatan atau aktivitas yang bermanfaat seperti menyapu dan mendengarkan teman mengobrol.

Komunikasi antar anggota dalam terapi akan meningkatkan rasa bangga, meningkatkan kepercayaan diri lansia dan merasa dihargai karena terjadi proses berbagi pengalaman, eksplorasi pendapat dari setiap sesi yang dilakukan sesama 
anggota, selain itu kegiatan berbagi dalam setiap sesi akan meningkatkan rasa kebersamaan antar anggota dan saling memotivasi antara yang satu dan yang lainnya yang akan membangkitkan konsep diri positif bagi lansia.

Pada sesi selanjutnya, terapis mengeksplorasi tentang lansia mempunyai harapan tersebut pada sesi pertama yang kemudian dihubungkan dengan makna yang terkandung dari harapan tersebut. Pada sesi ini secara tidak langsung lansia diajarkan untuk memiliki tujuan dalam hidup yang didapatkan dari harapan. Dengan adanya harapan dan tujuan hidup, lansia akan berupaya mewujudkan melalui kegiatan yang berguna bagi dirinya dan orang lain sehingga terhindar dari rasa bosan, hampa, putus asa, tidak berdaya, merasa tidak berguna dan dapat meningkatkan harga diri serta konsep diri lansia. Melalui logoterapi ini lansia akan mampu menciptakan dan membangkitkan pengalaman yang membawa lansia keluar dari kondisi tidak baik yang dirasakannya terutama karena proses menua (Frank, 2002).

Hal ini dipertegas oleh Bastaman bahwa melalui kegiatan dalam logoterapi, individu dibantu untuk menangani masalah yang mencakup 3 dimensi yaitu fisik, psikis, dan spirit.

\section{Makna hidup}

Berdasarkan hasil penelitian dapat diketahui bahwa sebagian besar lansia memiliki makna hidup tinggi. Data yang didapatkan dari 30 responden dengan persentase $66,6 \%$ sebanyak 20 responden berada pada kategori tinggi dan prosentase $3 \%$ dan sebanyak 1 responden berada pada kategori rendah. Lansia yang memiliki harga diri yang rendah juga berpengaruh pada konsep dirinya yang akan menjadi negatif sehingga ditemukan perasaan tidak berdaya, hampa, tidak berguna, bosan dan tidak memiliki tujuan hidup. Tanda dan gejala tersebut merupakan salah satu tanda dan gejala dari individu yang tidak berhasil menemukan dan memenuhi makna hidup. Menurut Frank (2011) tanda dan gejala yang ditemukan pada individu yang tidak memiliki dan memenuhi makna hidup dalam perjalanan hidupnya adalah perasaan hampa, apatis, merasa tidak berguna, bosan dan apatis

Logoterapi bertujuan untuk membangkitkan individu untuk memiliki kehidupan bermakna yang bersifat khusus dan pribadi bagi masing-masing orang. Seseorang dapat bertahan dalam kondisi yang tidak menguntungkan apabila tujuan tidak terpenuhi. Logoterapi bermanfaat pada lansia dalam menghadapi kesulitan agar hidupnya lebih bermakna.

Sesi kedua yaitu menggali harapan dan alasan yang dapat membangkitkan harapan hidup lansia. Hal ini bermanfaat untuk orang lain karena lansia mampu melakukan kegiatan rumah tangga seperti menyapu, merajut dan lain-lain.

\section{Simpulan}

Logoterapi menunjukkan hasil yang signifikan untuk meningkatkan kemampuan memaknai hidup pada lansia. Perawat dapat membantu untuk mengatur ketersediaan perangkat tenaga kesehatan keperawatan untuk mendukung terlaksananya terapi bagi lansia di masyarakat.

Hasil penelitian menyebutkan bahwa logoterapi efektif dalam meningkatkan harga diri dan makna hidup lansia sehingga dapat diterapkan bagi lansia.

\section{Daftar Pustaka}

Adiningsih, I.A. (2013). Hubungan antara Konsep Diri dan Makna Hidup pada Lansia di Unit Rehabilitasi Sosial Pucang Gading Semarang. Semarang: Unissula

Arikunto, S. (2006). Prosedur Penelitian Suatu Pendekatan Praktik (Edisi Revisi IV). Jakarta: Rineka Cipta. 
Azizah, Lilik M. (2011). Keperawatan Lanjut Usia. Yogyakarta: Graha Ilmu

Bastaman, H. D. (2007). Logoterapi: Psikologi untuk Menemukan Makna Hidup dan Meraih Hidup Bermakna. Jakarta: PT. Grafindo Persada.

Frank, EV. (2002). Mencari makna hidup: man searching fo meaning. Boston: Mc. Graw Hill

Frankl, V. E. (2011). Man's Search for Meaning: An Introduction to Logotherapy. New York: Washington Square Press. (Earlier title, 1959: From Death-Camp to Existentialism. Originally published in 1946 as Ein Psycholog erlebt das Konzentrationslager ), diperoleh tanggal 8 Februari 2013.

Gunadi, H. (1984). Problematik Usia Lanjut Ditinjau Dari Sudut Kesehatan Jiwa. Jakarta: Jiwa XVII(4): 89-97

Hawari, D. (2004). Al Qur'an Ilmu Kedokteran Jiwa dan Kesehatan Jiwa. Yogyakarta: PT. Dana Bakti Prima

Hurlock, E. B. (2008). Psikologi Perkembangan Edisi kelima. Jakarta: Erlangga

Kaplan, Sadock, \& Grebb. (2010). Sinopsis Psikiatri Ilmu Pengetahuan Perilaku Psikiatri Klinis Jilid 1. Tangerang: Bina Putra Aksara

Lewis, M.H. (2010). Guide to the fundamental principles of Viktor E. Franks logotherapy. Canada.

Miler, A.C. (2004). Nursing Care of Older Adult Theory and practice.third edition.Philadelpia:

J.B.Lippincott.Co
Nauli, F.A. (2011). Pengaruh Logoterapi dan Psikoedukasi Keluarga terhadap Depresi dan Kemampuan memaknai Hidup

Nisfulaili, Y. (2010). Hubungan Antara Konsep Diri dan Kebermaknaan Hidup Kaum Waria di IWAMA (Ikatan Waria Malang). http://lib.uinmalang.ac.id/thesis/fullchapter/0541 0021-yulia-nisfulaili.ps. Diperoleh12 Februari 2013.

Stuart, G.W. (2010). Principles and practice of psychiatric nursing. $10^{\text {th }}$ ed. Canada: Mosby, Inc 